\title{
Aikuiskasvatuksen tulevaisuus Etelä-Afrikassa -konferenssi
}

Hararessa Zimbabwessa pidettiin 21.1.-2.2.1989 kansainvälinen konferenssi, jonka aiheena oli aikuiskasvatuksen tulevaisuus EteläAfrikassa. Konferenssia edelsi kaksipäiväinen Kansainvälisen aikuiskasvatusjärjestön ICAE:n hallituksen kokous. Konferenssissa keskityttiin lähinnä Etelä-Afrikan ja Namibian aikuiskasvatukseen ja etsittiin keinoja, joilla näiden kahden maan edistyksellisiä aikuiskasvattajia voitaisiin tukea, koska sekä Etelä-Afrikassa että Namibiassa tarjotaan apartheid-hallinnon takia sorretuille hyvin vähän virallista koulutusta; siksi näissä maissa on vähemmän aikuiskasvatustakin.

Konferenssi oli ensimmäinen laatuaan ja siihen osallistui aikuiskasvattajia ympäri maailmaa. He saapuivat paikalle keskustellakseen Etelä-Afrikasta ja Namibiasta tulleiden edistyksellisten aikuiskasvattajien kanssa. Konferenssissa todettiin, että aikuiskasvatuslaitokset ja -järjestöt jäisivät norsunluutorneiksi, jos ne olisivat piittaamatta rotusortoa harjoittavan Etelä-Afrikan äärimmäisen vaikeissa olosuhteissa työskentelevien edistyksellisten aikuiskasvattajien pyrkimyksistä. Edelleen tunnustettiin, että muu maailma voi oppia näiden kahden maan kokemuksista.

Konferenssiin osallistui parisen sataa ihmistä 40 eri maasta ja 10 järjestöstä. Konferenssin vetäjä totesi, että "aikuiskasvatusta on kohdeltu kasvatuksen Tuhkimona". Afrikan lukutaito- ja aikuiskasvatusjärjestön AALAE:n puheenjohtaja tri Anthony Sets'abi osoitti avauspuheenvuorossaan, että "meillä aikuiskasvattajilla ei ole poliittista forumia, jolla voisimme esiintyä, emmekä me voi antaa sellaista mitä meillä ei ole. Meillä on kuitenkin hallussamme joitakin niistä parhaista aseista, joita ihmisellä ylipäätään on. Meillä on aivot, meillä on näkemystä, meillä on filosofia ja koulutusstrategioita ja meillä on kieli ja kyniä. Me asetamme nämä apartheid-hallinnon alaisina elävien veljiemme ja sisartemme käyttöön."

Konferenssin järjestivät yhteis- työnä Kansainvälinen aikuiskasvatusjärjestö ICAE, Afrikan Lukutaitoja aikuiskasvatusjärjestö AALAE Lesothon Vapaan sivistystyön yhdistys ja Zimbabwen Aikuiskasvatuksen ja vapaan sivistystyön kansallinen järjestö.

\section{Konferenssin julkilausuma}

\section{Johdanto}

Tämä oli ensimmäinen konferenssi, johon kokoontui apartheidia vastaan taistelemaan sitoutuneita aikuiskasvattajia Etelä-Afrikasta ja Namibiasta, vapautusliikkeiden ${ }^{1}$, Etulinjan maiden ${ }^{2}$ ja muiden Afrikan maiden aikuiskasvattajia sekä osallistujia Aasiasta, Latinalaisesta Amerikasta, PohjoisAmerikasta ja Euroopasta.

Konferenssi kokoontui, koska asenteet Etelä-Afrikkaa kohtaan ovat muuttuneet niin että maahan kohdistuu nyt valikoiva boikotti. Konferenssi myöntää valikoivaan taloussaartoon sisältyvät ongelmat, mutta myöntää silti tarpeen tehdä ero hyökkääjän ja uhrin välille. Konferenssi uskoo myös, että valikoivaan boikottiin sisältyvät ongelmat voidaan minimoida, jos AALAE ryhtyy toimenpiteisiin neuvotellen tiiviisti Etelä-Afrikan ja $\mathrm{Na}$ mibian vapautusliikkeiden ja niiden liittolaisten kanssa.

Konferenssi vakuuttaa, että osallistuvien yksityisten ja järjestöjen tulisi tulkita oheiset päätöslausumat toimintaohjeena ja kehotuksina toimintaan.

Konferenssi myöntää AALAE:n olevan aikuiskasvattajien rikas ja dynaaminen kohtaamispaikka Afrikan mantereella ja että aikuiskasvattajat, jotka ovat sitoutuneet taistelemaan rotusorrosta vapaan demokraattisen yhteiskunnan puolesta Etelä-Afrikassa ja Namibiassa, hyötyvät osallistumalla siihen. Siksi me kehotamme osallistuvia yksityisiä ja järjestöjä selvittämään tosissaan mahdollisuudet jatkotoimiin seuraavilla tasoilla:

1. Yhteyksien solmiminen ja vaihto Etelä-Afrikassa ja Namibiassa.

2. Yhteyksien solmiminen ja vaihto Etulinjan maiden kanssa.

3. Yhteyksien solmiminen ja vaihto muiden itsenäisten Afrikan maiden kanssa.

4. Osallistuminen AALAE:n toimintoihin.

5. Yhteyksien solmiminen Aasian, Latinalaisen Amerikan, Pohjois-Amerikan ja Euroopan alueellisten aikuiskasvatusliikkeiden kanssa.

6. Osallistuminen ICAE:n toimintoihin.

\section{Solidaarisuustoimet}

Me torjumme Etelä-Afrikassa pöydälle asetetun lakiesityksen, joka koskee ulkomaisen rahoituksen paljastamista ja jonka tarkoituksena on muun muassa katkaista ulkomailta tuleva apu demokraattisissa kansanliikkeissä toimiville järjestöille. Lain voimaantulo vaikuttaisi tuhoisasti edistyksellisen liikkeen aikuiskasvatustyöhön, koska se on täysin riippuvaista yksityisestä rahoituksesta.

Painostaakseen Etelä-Afrikan hallitusta olemaan panematta lakiesitystä täytäntöön konferenssi suosittelee:

a) että kaikkien kansakuntien huomio kiinnitetään lakiesitykseen Afrikan yhtenäisyysjärjestön (OAU:n), Yhdistyneiden Kansakuntien ja muiden asiaankuuluvien elinten välityksellä, jotta lakiesitys tuomittaisiin mahdollisimman voimaperäisesti.

b) että Etelä-Afrikan ja Namibian aikuiskasvatustyötä tällä hetkellä tukevia lahjoittajia kehotetaan vastustamaan Etelä-Afrikan hallituksen pyrkimyksiả estää tähän työhön tarkoitetun ulkomaisen rahoituksen tulo. Me kehotamme lahjoittajia - jos uusi ulkomaisen rahoituksen paljastamista koskeva lakiesitys astuu voimaan - etsimään keinoja, joilla taataan varojen jatkuva tulo maahan, samoin kuin kehotamme rohkaisemaan lahjoittajia pitämään kiinni sitoumuksistaan aikuiskasvatustyölle.

\section{Päätöslauselmat}

1. että lahjoittajia kannustetaan tukemaan Etelä-Afrikassa ja Nami- 
biassa toimivia vapautusliikkeitä sekä niiden liittolaisia.

2. että AALAE ja ICAE laativat Afrikan sisäiset vaihto-ohjelmat Etelä-Afrikassa ja Namibiassa toimivien vapautusliikkeiden ja niiden liittolaisten aikuiskasvatusedustajille.

3. että AALAE ja ICAE kannustavat ja helpottavat Etelä-Afrikassa ja Namibiassa sekä niiden vapautusliikkeissä toimivien aikuiskasvatusjärjestöjen ja muissa Afrikan maissa toimivien vastaavien järjestöjen kesken tapahtuvaa tiedon- ja materiaalinvaihtoa.

4. että AALAE ja ICAE kannustavat ja helpottavat Etelä-Afrikan ja Namibian sekä vapautusliikkeiden aikuiskasvattajien osallistumista kansainvälisiin tapahtumiinsa.

5. että Kansainvälisen lukutaitovuoden kansainvälisiä lukutaitojoukkoja pyydetään saattamaan koko maailman tietoisuuteen ne olosuhteet, jotka estävät lukutaidon edistämistä Etelä-Afrikassa ja Namibiassa.

6. että AALAE.n ja ICAE:a pyydetään valmistamaan raportti EteläAfrikan ja Namibian aikuiskasvatustilanteesta ja levittämään se laajasti.

7. että Etelä-Afrikassa ja Namibiassa sekä vapautusliikkeissä toimivien ja muissa maissa toimivien kansalaisjärjestöjen kesken solmitaan yhteyksiä.

8. että perustetaan aikuiskasvatuksen koulutukseen ja voimavarojen kehittämiseen tarkoitettuja toimielimiä.

9. että Afrikassa ja muualla maailmassa toimivat sisarjärjestöt järjestävät kursseja Etelä-Afrikan ja Namibian sekä vapautusliikkeiden kansalaisjärjestöille, kouluttajille ja yhteisöjen työntekijöille.

10. koska naisilla on tärkeä osa Etelä-Afrikan ja Namibian itsenäisyystaistelussa ja koska suurella määrällä naisista on sangen rajoitetut koulutusmahdollisuudet, että AALAE ja ICAE harkitsisivat sellaisten aikuiskoulutusohjelmien kehittämistä, jossa kiinnitetään erityinen huomio naisiin.

11. että Etelä-Afrikassa ja Namibiassa sekä vapautusliikkeissä toimivien kansalaisjärjestöjen välisiä yhteyksiä tuetaan.

\footnotetext{
1 Vapautusliikkeillä tarkoitetaan tässä esitelmässä ANC:a ja SWAPO:a.

${ }^{2}$ Etulinjan mailla tarkoitetaan 9 eteläisen Afrikan SADDC-maata.
} 